\title{
PERBEDAAN HASIL BELAJAR MATEMATIKA SISWA KELAS VIII YANG MEMPEROLEH PEMBELAJARAN DENGAN PROBLEM BASED LEARNING DAN PROBLEM SOLVING
}

\author{
Tuti Erlisa ${ }^{1, \text { a) }}$ Suryatul Aini Asyhara ${ }^{2, b)}$ Noprisa $^{2, c)}$ \\ ${ }^{2}$ Universitas Muhammadiyah Metro, Iringmulyo, Kota Metro, Lampung 34381 \\ ${ }^{2}$ Universitas Muhammadiyah Lampung, Jl. H. Zainal Abidin Pagar Alam No. \\ 14, Bandar Lampung \\ e-mail: ${ }^{a}$ erlisatuti790@gmail.com \\ b)asyharaaini@gmail.com \\ c)noprisaica@gmail.com
}

\begin{abstract}
The purpose of this study was to determine whether there was a difference in the average learning outcomes of mathematics and which one was the higher average of mathematics learning outcomes between students who used Problem Based Learning and Problem Solving learning methods. This type of research is experimental. The data analysis technique uses the ttes formula. The results show that: (1) there is a difference in the average learning outcomes of mathematics between students who use the Problem Based Learning and Problem Solving learning methods at SMPN 2 Metro, it is known that based on the calculation of the hypothesis test obtained thit $=$ 2.60 and tdaf $=2,00$ so thit $>$ tdaf. (2) the average learning outcomes of students who use the Problem Based Learning learning method are higher than the Problem Solving learning method in mathematics learning for class VIII.
\end{abstract}

Keywords: Learning Outcomes, Problem Based Learning, Problem Solving

\begin{abstract}
Abstrak
Tujuan penelitian ini adalah untuk mengetahui apakah ada perbedaan rata-rata hasil belajar matematika dan manakah yang lebih tinggi rata-rata hasil belajar matematika antara siswa yang menggunakan metode pembelajaran Problem Based Learning dan Problem Solving. Jenis penelitian ini adalah eksperimen. Teknik analisis data menggunakn rumus $t_{\text {tes. }}$. Hasil
\end{abstract}


penelitian menunjukkan bahwa: (1) ada perbedaan rata-rata hasil belajar matematika antara siswa yang menggunakan metode pembelajaran Problem Based Learning dan Problem Solving di SMPN 2 Metro, hal ini diketahui berdasarkan perhitungan uji hipotesis diperoleh $t_{\text {hit }}=2,60$ dan $t_{\text {daf }}=2,00$ jadi $t_{\text {hit }}>t_{\text {daf }}$. (2) rata-rata hasil belajar siswa yang menggunakan metode pembelajaran Problem Based Learning lebih tinggi daripada metode pembelajaran Problem Solving dalam pembelajaran matematika siswa kelas VIII.

Kata kunci: Hasil Belajar, Metode Problem Based Learning dan Metode Problem Solving

\section{PENDAHULUAN}

Manusia sebagai makhluk yang diberi kelebihan oleh Allah SWT dengan suatu bentuk akal pada diri manusia yang tidak dimiliki makhluk Allah yang lain dalam kehidupannya. Untuk mengolah akal pikirnya diperlukan suatu pola pendidikan melalui suatu proses pembelajaran. Pendidikan merupakan salah satu kebutuhan pokok dalam kehidupan manusia yang memikirkan bagaimana menjalani kehidupan ini untuk mempertahankan hidup manusia yang mengemban tugas dari Sang Kholiq untuk beribadah.

Seseorang dalam menjalani hidup tidak terlepas dari masalah, begitu pun pada dunia pendidikan. Kemampuan siswa dalam memecahkan masalah dipandang sebagai suatu tolak ukur yang dapat mempengaruhi hasil belajar siswa, selain kemampuan pemecahan masalah tersebut, penggunaan metode pembelajaran yang tepat juga sangat mempengaruhi hasil belajar siswa. Hasil belajar yang sesuai dengan metode yang diterapkan diharapkan dapat meningkat dan memenuhi kriteria ketuntasan belajar ideal untuk setiap indikator yaitu 0 - 100\%, dengan batas kriteria ideal minimum 75\% [1].

Berdasarkan hasil pra survey di SMP Negeri 2 Metro terkait hasil belajar siswa bidang studi matematika kelas VIII dapat diketahui bahwa hasil belajar siswa masih relatif rendah dan perlu untuk ditingkatkan. Hal ini terlihat dari siswa yang nilai hasil belajarnya 
mencapai Kriteria Ketuntasan Minimal (KKM) 75 sebanyak 15 siswa atau 47\% dari 32 siswa yang tuntas, sedangkan siswa yang nilai KKM < 75 sebanyak 17 siswa atau 53\%. Hal ini menunjukkan bahwa proses pembelajaran masih jauh dari apa yang diharapkan.

Oleh karena itu perlu adanya pembaharuan pembelajaran dengan penggunaan metode yang tepat agar hasil belajar siswa dapat ditingkatkan sesuai dengan kriteria ketuntasan ideal yang telah ditetapkan sebagai suatu patokan keberhasilan dalam pembelajaran. Seorang guru diharapkan memiliki kemampuan merancang dan mengimplementasikan berbagai metode pembelajaran yang cocok dengan minat dan bakat serta sesuai dengan karakteristik siswa agar mampu mengorganisasikan materi serta mengantisipasi masalahmasalah yang timbul dalam pembelajaran.

Metode pembelajaran dalam pendidikan merupakan bagian yang penting dalam proses belajar mengajar karena metode pembelajaran merupakan cara yang digunakan untuk mengimplementasikan rencana yang sudah disusun dalam bentuk kegiatan nyata dan praktis untuk mencapai tujuan pembelajaran. Dalam rangka peningkatan kualitas dalam melaksanakan proses belajar mengajar, maka diperlukan penekanan bagi setiap guru bidang studi dalam mengajar hendaknya dapat memilih metode pembelajaran yang tepat dengan bahan kajian yang akan diajarkan dan dipelajari siswa.

Berdasarkan permasalahan di atas siswa membutuhkan metode pembelajaran yang tepat untuk meningkatkan hasil belajar. Salah satu metode yang dapat diterapkan untuk meningkatkan hasil belajar siswa adalah metodepembelajaran Problem Based Learning. Tujuan dari penelitian ini adalah (1) Mengetahui perbedaan rata-rata hasil belajar siswa antara yang menggunakan metode pembelajaran Problem Based Learningdan metode pembelajaran Problem Solving dalam pembelajaran matematika siswa kelas VIII SMP Negeri 2 Metro. (2) Mengetahui manakah yang lebih tinggi rata-rata hasil belajar matematika siswa antara yang menggunakan metode pembelajaran Problem Based Learning dan metode pembelajaran Problem Solving siswa kelas VIII SMP Negeri 2 Metro. 
Riyanto menyatakan bahwa: "Pembelajaran berbasis masalah adalah suatu metode pembelajaran yang menuntut peserta didik untuk berpikir kritis, memecahkan masalah, belajar secara mandiri, dan menuntut keterampilan berpartisipasi dalam tim" [2]. Amir menyatakan bahwa ada 7 langkah proses PBL mengklarifikasi istilah dan konsep yang belum jelas, merumuskan masalah, menganalisis masalah, menata gagasan dan secara sistematis menganalisisnya dengan dalam, memformulasikan tujuan pembelajaran, mencari informasi tambahan dari sumber yang lain (di luar diskusi kelompok), mensintesa (menggabungkan) dan menguji informasi baru dan membuat laporan [3].

Berdasarkan pendapat di atas dapat diketahui langkah-langkah dalam Problem Based Learning yaitu merumuskan masalah, menganalisisnya untuk mencari solusi dengan menata gagasan secara sistematis dari setiap anggota kelompok, agar tujuan pembelajaran yang telah direncanakan diawal dapat tercapai dengan mencari berbagai sumber informasi yang dapat dijadikan rujukan untuk menyelesaikan masalah tersebut dengan baik sampai pada menguji kebenaran atas solusi yang telah dirumuskan dengan cara membuat laporan untuk dipresentasikan.

Menurut J. Dewey bahwa: Ada enam tahap yang ada dalam pemecahan masalah yaitu merumuskan masalah, menelaah masalah, merumuskan hipotesis, mengumpulkan dan mengelompokkan data sebagai bahan pembuktian hipotesis, pembuktian hipotesis, dan menentukan pilihan penyelesaian [4]. Sedangkan Ngalimun menyatakan bahwa "Masalah didefinisikan sebagai suatu persoalan yang tidak rutin, belum dikenal cara penyelesaiannya. Justru Problem Solvingadalah mencari atau menemukan cara penyelesaian" [5].

Kemudian Sanjaya [1] menyatakan bahwa keunggulan dan kelemahan Problem Solving yaitu:

1. Keunggulan

a) pemecahan masalah (Problem Solving) merupakan teknik yang cukup bagus untuk lebih memahami isi pelajaran. 
b) Pemecahan masalah (Problem Solving) dapat menantang kemampuan siswa serta memberikan kepuasan untuk menemukan pengetahuan baru bagi siswa.

c) Pemecahan masalah (Problem Solving) dapat meningkatkan aktivitas pembelajaran siswa.

d) Pemecahan masalah (Problem Solving) dapat membantu siswa bagaimana mentransfer pengetahuan mereka untuk memahami masalah dalam kehidupan nyata.

e) Pemecahan masalah (Problem Solving) dapat membantu siswa untuk mengembangkan pengetahuan barunya dan bertanggung jawab dalam pembelajaran yang mereka lakukan.

f) Melalui pemecahan masalah (Problem Solving) bisa memperlihatkan kepada siswa bahwa setiap mata pelajaran pada dasarnya merupakan cara berfikir, dan sesuatu yang harus dimengerti pleh siswa, bukan hanya sekedar belajar dari guru atau dari buku-buku saja.

g) Pemecahan masalah (Problem Solving) dianggap lebih menyenangkan dan disukai siswa.

h) Pemecahan masalah (Problem Solving) dapat mengembangkan kemampuan siswa untuk berfikir kritis dan mengembangkan kemampuan mereka untuk menyesuaikan dengan pengetahuan baru.

i) Pemecahan masalah (Problem Solving) dapat memberikan kesempatan kepada siswa untuk mengaplikasikan pengetahuan yang mereka miliki dalam dunia nyata.

j) Pemecahan masalah (Problem Solving) dapat mengembangkan minat siswa untuk secara terus-menerus belajar sekalipun belajar pada pendidikan formal telah berakhir.

2. Kelemahan

a) Mana kala siswa tidak memiliki minat atau tidak mempunyai kepercayaan bahwa masalah yang dipelajari sulit untuk dopecahkan, maka mereka merasa enggan untuk mencoba. 
b) Keberhasilan pembelajaran melalui problem solving membutuhkan cukup waktu untuk persiapan.

c) Tanpa pemahaman mengapa mereka berusaha untuk memecahkan masalah yang sedang dipelajari, maka mereka tidak akan belajar apa yang mereka ingin pelajari.

Berdasarkan pendapat di atas dapat diketahui bahwa metode problem solving juga merupakan metode yang memiliki kekurangan dan kelebihan. Oleh karena itu dalam pembelajaran hendaknya mampu mengoptimalkan kelebihan metode ini dan meminimalisir kekurangannya. Sehingga apa yang diharapkan dalam pembelajaran menggunakan metode Problem Solving dapat tercapai. Sedangkan solusi yang dapat digunakan untuk mengatasi kelemahan metode Problem Solvingyaitu dengan memberikan pemahaman pada siswa terkait kegunaan dari pemecahan masalah yang mereka lakukan serta memberikan rewardkepada siswa yang mampu memecahkan masalah yang sedang dihadapi.

Sanjaya menyatakan "Belajar adalah berbuat dengan aktivitas, siswa bukan hanya dituntut untuk menguasai sejumlah informasi dengan cara menghafal, akan tetapi bagaimana memperoleh informasi secara mandiri dan kreatif melalui aktivitas mencari dan menemukan" [1]. Sedangkan Piaget (dalam Karwono dan Heni Mularsih) menyatakan bahwa "Belajar disebut juga perkembangan. Belajar merupakan proses mengolah informasi dalam rangka membangun sendiri pengetahuannya" [6].

\section{METODE PENELITIAN}

Rancangan penelitian yang akan dilakukan dalam penelitian ini adalah salah satu penelitian yang bersifat kuantitatif, yang bertujuan meningkatkan hasil belajar matematika siswa. Pada penelitian ini jenis penelitian yang dilakukan adalah eksperimen semu. Populasi dalam 
penelitian ini adalah seluruh siswa kelas VIII, pengambilan sampel dalam penelitian ini menggunakan teknik Stratified Random Sampling dan ternyata yang terpilih dalam penelitian ini adalah kelas VIIIA dan VIIIB dimana peneliti menggunakan metode Problem Based Learning pada siswa kelas VIIIA dan metode Problem Solving pada siswa kelas VIIIB dalam proses pembelajarannya.

Adapun alat ukur atau tes hasil belajar yang digunakan dalam penelitian ini adalah validitas isi. Reliabilitas digunakan untuk mencari keajegan dari instrumen yang akan digunakan dalam tes. Teknik pengumpulan datanya menggunakan tes tertulis, sedangkan analisis datanya menggunakan rumus statistika. Pengujian hipotesis menggunakan uji-t, adapun persyaratan yang harus dipenuhi sebelum uji-t dilakukan adalah data harus berdistribusi normal dan homogen. Sebelum penelitian dilaksanakan, kelas yang dijadikan sampel juga perlu uji keseimbangan terlebih dahulu, pada penelitian ini uji keseimbangan menggunakan nilai ulangan harian materi persamaan garis.

\section{HASIL DAN PEMBAHASAN}

\subsection{Hasil Penelitian}

\section{Deskripsi Data Hasil Belajar Siswa di Kelas VIII A}

Setelah peneliti mengadakan tes hasil belajar di kelas VIII A yang dalam pembelajarannya menggunakan metode pembelajaran Problem Based Learning pada materi Sistem Persamaan Linier Dua Variabel diperoleh data sebagai berikut: 
Tabel 1. Skor hasil belajar siswa yang memperoleh pembelajaran Problem

\begin{tabular}{|c|c|c|c|c|c|}
\hline & & & & & \\
\hline No & Nama Siswa & Skor & No & Nama Siswa & Skor \\
\hline 1 & Almada Pubiana & 60 & 16 & Intan Widyaningrum & 96 \\
\hline 2 & $\begin{array}{c}\text { Amelia Nur } \\
\text { Afifah }\end{array}$ & 100 & 17 & Irsyifa Mayzela Afnan & 75 \\
\hline 3 & Anisa Putri & 90 & 18 & Izelia Artiana & 100 \\
\hline 4 & Anisa Zakiyah & 90 & 19 & Jovita Octa Meylinda & 80 \\
\hline 5 & $\begin{array}{l}\text { Annisa Diah } \\
\text { Pertiwi }\end{array}$ & 63 & 20 & Lena Meriyana & 80 \\
\hline 6 & $\begin{array}{c}\text { Cesara Titania } \\
\text { Aurel }\end{array}$ & 75 & 21 & Leni Meriyani & 70 \\
\hline 7 & $\begin{array}{l}\text { Chairini Nur } \\
\text { Aq'sa }\end{array}$ & 90 & 22 & Lutfia Indah Palupi & 75 \\
\hline 8 & Clarisawati & 80 & 23 & Maharani Elvida & 80 \\
\hline 9 & Eky Rahmawati & 80 & 24 & Monica Yolanda Sari & 53 \\
\hline 10 & Era Fadilahwati & 75 & 25 & Oktavia Ningsih & 80 \\
\hline 11 & Elvina Triani & 90 & 26 & Retno Palupi & 80 \\
\hline 12 & Fellany Amalia & 62 & 27 & Rossy M. Khasanah & 85 \\
\hline 13 & $\begin{array}{c}\text { Gesia Afifah Ayu } \\
\text { W. }\end{array}$ & 67 & 28 & Shelly Meisita Sari & 90 \\
\hline 14 & Hamdah & 75 & 29 & Shalwa Syifa & 88 \\
\hline 15 & $\begin{array}{l}\text { Ichsan Nanda } \\
\text { Ramadhan }\end{array}$ & 80 & 30 & Yulia Rinta Amelia & 68 \\
\hline
\end{tabular}

Berdasarkan data hasil belajar tersebut, diperoleh rata-rata hasil belajar siawa kelas VIII A yang dalam pembelajarannya menggunakan metode Problem Based Learning pada pokok bahasan sistem persamaan linier dua variabel yaitu 79,16. Nilai tertinggi yang diperoleh adalah 100 dan nilai terendah yang diperoleh adalah 53.

\section{Deskripsi Data Hasil Belajar Siswa di Kelas VIII B.}

Setelah penulis mengadakan tes hasil belajar di kelas VIII B yang dalam pembelajarannya menggunakan metode pembelajaran Problem Solving pada materi sistem persamaan linier dua variabel diperoleh data sebagai berikut: 
Tabel 2. Skor hasil belajar siswa yang memperoleh pembelajaran dengan

\begin{tabular}{|c|c|c|c|c|c|}
\hline No & Nama Siswa & Skor & No & Nama Siswa & Skor \\
\hline 1 & Adha Mirmaska & 80 & 16 & Karina Fitri Wulandari & 30 \\
\hline 2 & Agiska Ayu & 75 & 17 & Luthfi Abir & 35 \\
\hline & Kurniasari & & & & \\
\hline 3 & Ari Yosita & 75 & 18 & Meizta Wanti & 85 \\
\hline 4 & $\begin{array}{l}\text { Ayu Bunga } \\
\text { Lestari }\end{array}$ & 85 & 19 & Mirhandika Febytry & 93 \\
\hline 5 & Azis Khurniawan & 85 & 20 & Muh. Agung Putra & 100 \\
\hline 6 & Bagas Alfani & 98 & 21 & Muhammad Nalom Syah & 45 \\
\hline 7 & $\begin{array}{l}\text { Bayu Dwi } \\
\text { Aprilianto }\end{array}$ & 40 & 22 & Muhammad Regeng R. & 25 \\
\hline 8 & $\begin{array}{c}\text { Diana Kartika } \\
\text { Sari }\end{array}$ & 45 & 23 & Rafena Sunja Urmila & 63 \\
\hline 9 & Dwi Yuni Astuti & 100 & 24 & $\begin{array}{c}\text { Rahma Mika Sari } \\
\text { Kusuma }\end{array}$ & 90 \\
\hline 10 & $\begin{array}{c}\text { Eka Apri Salfitah } \\
\text { Senda }\end{array}$ & 25 & 25 & Riska Angraini & 98 \\
\hline 11 & $\begin{array}{l}\text { Eka Rahma } \\
\text { Yulianti }\end{array}$ & 98 & 26 & Roby Kurniawan & 65 \\
\hline 12 & $\begin{array}{l}\text { Febby Ari } \\
\text { Wibowo }\end{array}$ & 70 & 27 & Sandi Sanjaya & 78 \\
\hline 13 & Filhaq Karizqi & 53 & 28 & Suranti Indriastita & 40 \\
\hline 14 & Hilda Saputri & 45 & 29 & Syafira Putri Kinanti & 60 \\
\hline 15 & $\begin{array}{l}\text { Juwanda } \\
\text { Prasetva }\end{array}$ & 40 & 30 & Syukron Aditya Wardani & 50 \\
\hline
\end{tabular}

Berdasarkan data hasil belajar tersebut, diperoleh rata-rata hasil belajar siawa kelas VIII B yang dalam pembelajarannya menggunakan metode Problem Solving pada pokok bahasan sistem persamaan linier dua variabel yaitu 65,27. Nilai tertinggi yang diperoleh adalah 100 dan nilai terendah yang diperoleh adalah 25.

\section{Uji Hipotesis}

\subsubsection{Uji Normalitas}

Uji normalitas data skor siswa yang dalam pembelajarannya menggunakan metode pembelajaran Problem Based Learning.

\section{Rumusan Hipotesis}

$\mathrm{H}_{0}$ : Sampel diambil dari populasi yang berdistribusi normal $\mathrm{H}_{1}$ : Sampel diambil dari populasi yag berdistribusi tidak normal

Berdasarkan hasil perhitungan (dapat dilihat pada lampiran 4.11) pada taraf signifikasi 0,05 menunjukkan $\chi_{\text {hit }}^{2}<\chi_{\text {daf }}^{2}$, yaitu $4,657<7,81$ hal ini berarti kesimpulannya terima $\mathrm{H}_{0}$ yaitu sample berasal dari populasi yang berdistribusi normal. 
Uji normalitas data hasil belajar siswa yang dalam pembelajarannya menggunakan metode pembelajaran Problem Solving

Rumusan hipotesis:

$\mathrm{H}_{0}$ : Sampel diampil dari populasi yang berdistribusi normal.

$\mathrm{H}_{1}$ : Sampel diambil dari populasi yang berdistribusi tidak normal.

Berdasarkan hasil perhitungan (dapat dilihat pada lampiran 4.12), pada taraf signifikasi 0,05 menunjukkan $\chi_{\text {hit }}^{2}<\chi_{\text {daf }}^{2}$, yaitu $7,18<7,81$ hal ini berarti kesimpulannya terima $H_{0}$ yaitu sample berasal dari populasi yang berdistribusi normal.

\subsubsection{Uji Homogenitas}

Rumusan hipoteis:

$\mathrm{H}_{0}: \sigma_{1}^{2}=\sigma_{2}^{2}$ (kedua populasi memiliki varians yang homogen)

$\mathrm{H}_{1}: \sigma_{1}^{2}=\sigma_{2}^{2}$ (kedua populasi memiliki varians yang tidak homogen)

Berdasarkan hasil perhitungan(dapat dilihat pada lampiran 4.13), terlihat bahwa pada taraf signifikasi 0,05 menunjukan bahwa $1,77<1,87$ yang berarti terima Ho dengan kata lain kedua populasi memiliki varians yang sama (homogen).

\subsubsection{Uji T}

Uji kesamaan dua rata-rata

Berdasarkan hasil perhitungan terlihat bahwa pada taraf signifikasi 0,05 menunjukkan bahwa 2,60 > 2,00 dengan demikian tolak Ho yang berarti terima $\mathrm{H}_{1}$ yang artinyaada perbedaan ratarata hasil belajar antara siswa yangdalam pembelajarannya menggunakan metode pembelajaran Problem Based Learning dan siswa yang dalam pembelajarannya menggunakan metode pembelajaran Problem Solving.

Uji Perbedaan dua rata-rata

Berdasarkan hasil perhitungan (dapat dilihat pada lampiran 4.14) terlihat bahwa pada taraf signifikasi 0,05 menunjukkan bahwa yaitu 2,53>1,67 dengan demikian kesimpulan yang diperoleh adalah terima $\mathrm{H}_{0}$ yang berarti rata-rata hasil belajar matematika siswa kelas VIII SMP Negeri 2 Metro yang pembelajarannya menggunakan metode pembelajaran Problem Based Learninglebih tinggi dari rata-rata hasil belajar matematika siswa yang pembelajarannya menggunakan metode pembelajaran Problem Solvingpada pokok bahasan Sistem persamaan linear dua variabel.. 


\subsection{Pembahasan}

Berdasarkan hasil analisis data hasil belajar diperoleh hasil penelitian yang sesuai dengan rumusan masalah bahwa:

1) Ada perbedaan rata-rata hasil belajar siswa antara yang menggunakan metode pembelajaran Problem Based Learning dengan rata-rata hasil belajar siswa yang dalam pembelajarannya mengunakan metode pembelajaran Problem Solving pada materi pokok Sistem Persamaan Linier Dua Variabel siswa kelas VIII semester ganjil SMP Negeri 2 Metro dengan hasil perhitungan uji hipotesis diperoleh $t_{h i t}=2,60$ lebih besar dari $t_{d a f}=2,00$ (pada taraf signifikansi 0,05) atau dilambangkan $t_{h i t}>t_{d a f}$ yang mana diperoleh kriteria uji tolak $H_{0}$ dan terima $\mathrm{H}_{1}$.

Adanya perbedaan rata-rata hasil belajar siswa dapat diketahui sesuai dengan langkah-langkah pembelajaran pada masing-masing metode pembelajaran yang digunakan, hal ini senada dengan pendapat Amir (2009:24) yang menyatakan bahwa "ada 7 langkah proses PBL mengklarifikasi istilah dan konsep yang belum jelas, merumuskan masalah, menganalisis masalah, menata gagasan dan secara sistematis menganalisisnya dengan dalam, memformulasikan tujuan pembelajaran, mencari informasi tambahan dari sumber yang lain (di luar diskusi kelompok), mensintesa (menggabungkan) dan menguji informasi baru dan membuat laporan".

Sedangkan Menurut Djamarah menyatakan bahwa langkahlangkah penggunaan metode Problem Solving adalah “(a) Adanya masalah yang jelas untuk dipecahkan. (b) Mencari data atau keterangan yang dapat dipergunakan untuk memecahkan masalah tersebut. (c) Menetapkan jawaban sementara dari masalah tersebut. (d) Menguji kebenaran jawaban sementara tersebut. (e) Menarik kesimpulan" [7].

Berdasarkan kedua pendapat di atas dapat diketahui secara jelas bahwa ada perbedaan pada langkah-langkah pembelajaran yang dilaksanakan Dimana pada metode pembelajaran Problem Based Learning siswa tidak hanya dituntut mampu menyelesaikan masalah akan tetapi siswa juga dituntut untuk mampu bekerja sama untuk melaporkan hasil kerja mereka, sehingga mempengaruhi hasil belajar yang diperoleh siswa, yang menjadikan hasil belajar siswa tersebut berbeda. Selanjutnya dapat dilihat hasil penelitian yang sesuai dengan rumusan masalah pada metode mana yang lebih efektif. 
2) Rata-rata hasil belajar matematika siswa yang dalam pembelajarannya menggunakan metode pembelajaran Problem Based Learning lebih tinggi dari rata-rata hasil belajar siswa yang dalam pembelajarannya mengunakan metode pembelajaran Problem Solving pada materi pokok Sistem Persamaan Linier Dua Variabel siswa kelas VIII semester ganjil SMP Negeri 2 Metro dengan hasil perhitungan uji perbedaan dua rata-rata diperoleh $t_{\text {hit }}=2,53$ lebih besar dari $t_{d a f}=1,67$ (pada taraf signifikansi 0,05) atau dilambangkan $t_{h i t}>t_{d a f}$ yang mana diperoleh kriteria uji terima $H_{0}$.

Selanjutnya untuk mengetahui manakah hasil belajar yang lebih tinggi antara yang menggunakan metode pembelajaran Problem Based Learning dan yang mengunakan metode pembelajaran Problem Solving dapat diketahui sesuai dengan pendapat Arends yang mengidentifikasikan 6 keunggulan pembelajaran dengan metode pembelajaran Problem Based Learning, yakni: (1) siswa lebih memahami konsep yang diajarkan sebab mereka sendiri yang menemukan konsep tersebut, (2) menuntut keterampilan berpikir tingkat tinggi untuk memecahkan masalah, (3) pengetahuan tertanam berdasarkan skemata yang dimiliki peserta didik sehingga pembelajaran lebih bermakna, (4) peserta didik dapat merasakan manfaat pembelajaran sebab masalah yang dikaji merupakan masalah yang dihadapi dalam kehidupan nyata, (5) menjadikan peserta didik lebih mandiri dan lebih dewasa, termotivasi, mampu memberi aspirasi dan menerima pendapat orang lain, menanamkan sikap sosial yang positif diantara peserta didik, (6) pengkondisian peserta didik dalam belajar kelompok yang saling berinteraksi, baik dengan guru maupun teman akan memudahkan peserta didik mencapai ketuntasan belajar [8]. Berdasarkan pendapat ini maka pembelajaran dengan metode pembelajaran Problem Based Learning tentunya lebih bermakna dan akan memberikan hasil yang lebih baik.

Secara teoritis, perbedaan tersebut didasarkan pada perbedaan tanggapan yang dilakukan oleh siswa selama mereka mengalami pengajaran dengan metode pembelajaran Problem Based Learning dan metode pembelajaran Problem Solving. Tanggapan yang diberikan oleh siswa yang diajar dengan metode Problem Based Learning, lebih aktif karena siswa ikut berpartisipasi langsung dalam proses pembelajaran yang sesuai dengan pokok bahasan yang diajarkan yaitu sistem persamaan linier dua variabel dimana dalam pelaksanaanya siswa terdiri dari kelompok yang beranggotakan 5 orang yang diusahakan aktif 
dalam proses pembelajaran tersebut dan bersifat heterogen dimana dalam kelompok tersebut dibentuk dari latar belakang yang berbeda-beda, baik siswa yang memiliki kemampuan akademis tinggi dengan siswa yang kemampuan akademisnya sedang atau rendah.

\section{KESIMPULAN DAN SARAN}

\subsection{Kesimpulan}

Berdasarkan hasil analisis data penelitian dan pembahasan, selanjutnya penelitian ini dapat disimpulkan bahwa:

1) Ada perbedaan rata-rata hasil belajar siswa yang dalam pembelajarannya menggunakan metode pembelajaran Problem Based Learning dengan rata-rata hasil belajar siswa yang dalam pembelajarannya mengunakanmetode pembelajaran Problem Solvingpada materi pokok Sistem Persamaan Linier Dua Variabel siswa kelas VIII semester ganjil SMP Negeri 2 Metro, dengan hasil analisis data $t_{h i t}=2,60>t_{d a f}=2,00$ (pada taraf signifikansi 0,05 ) yang artinya tolak $\mathrm{H}_{0}$ dan terima $\mathrm{H}_{1}$ sehingga ada perbedaan rata-rata hasil belajar siswa yang dalam pembelajarannya menggunakan metode pembelajaran Problem Based Learning dengan rata-rata hasil belajar siswa yang dalam pembelajarannya mengunakanmetode pembelajaran Problem Solving

2) Rata-rata hasil belajar matematika siswa yang dalam pembelajarannya menggunakan metode pembelajaran Problem Based Learning lebih tinggi dari rata-rata hasil belajar siswa yang dalam pembelajarannya mengunakanmetode pembelajaran Problem Solvingpada siswa kelas VIII semester ganjil SMP Negeri 2 Metro, dengan hasil analisis data $t_{\text {hit }}=2,53>t_{\text {daf }}=1,67$ (pada taraf signifikansi 0,05 ) yang artinya terima $\mathrm{H}_{0}$ dan tolak $\mathrm{H}_{1}$ sehingga ratarata hasil belajar siswa yang dalam pembelajarannya mengunakan metode pembelajaran Problem Based Learning lebih tinggi dari rata-rata hasil belajar siswa yang dalam pembelajarannya mengunakanmetode pembelajaran Problem Solving 


\subsection{SARAN}

Berdasarkan kesimpulan yang diperoleh selama melaksanakan penelitian dan hasil pengamatan dalam pelaksanaan penelitian, maka penulis mencoba mengemukakan saran-saran guna meningkatkan hasil belajar siswa dalam bidang studi matematika sebagai berikut:

a. Dalam rangka meningkatkan hasil belajar siswa bidang studi matematika, penggunaan metode pembelajaran Problem Based Learning dengan cara mengajak siswa lebih aktif dalam pembelajaran melalui pemecahan masalah secara kolaborasi kelompok untuk mencari solusi yang paling tepat atas masalah yang mereka hadapi serta menuntut refleksi pembelajaran agar pembelajaran selanjutnya bisa lebih baik.

b. Penggunaan metode pembelajaran juga sebaiknya disesuaikan dengan karakteristik siswa karena semua metode pembelajaran pasti memiliki kelebihan dan kekurangan masing-masing.

Guru sebagai pelaksana proses pendidikan hendaknya mampu melakasanakan tugas pengajaran itu dengan baik dan yang dapat mengajak siswa aktifdalam proses pembelajaran serta dapat memotivasi siswa untuk belajar lebih giat.

\section{DAFTAR PUSTAKA}

[1] Sanjaya, Wina.2008. Strategi Pembelajaran Berorientasi Standar Proses Pendidikan. Jakarta: Prenada Media Group.

[2] Riyanto, Yatim. 2010. Paradigma Baru Pembelajaran. Jakarta: Prenada Media Group.

[3] Amir, M.Taufiq. 2009. Inovasi Pendidikan Melalui Problem Based Learning.Jakarta: Prenada Media Group

[4] Thobroni, Muhammad dan Arif Mustofa. 2011. Belajar dan Pembelajaran. Yogyakarta: Ar-Ruzz Media

[5] Ngalimun. 2013. Strategi dan Model Pembelajaran. Yogyakarta: Aswaja Pressindo.

[6] Karwono dan Heni Mularsih. 2010. Belajar dan Pembelajaran Serta Pemanfaatan Sumber Belajar. Ciputat: Cerdas Jaya.

[7] Djamarah, Syaiful Bahri. 2010. Strategi Belajar Mengajar. Jakarta: Rineka Cipta.

[8] Arend, Richard. 2008. Learning to Teach. Yogyakarta: Pustaka Pelajar. 